\title{
Phytoprotection
}

\section{A note on four nonradioactive labeling systems for dot hybridization detection of potato viruses}

\author{
P. Audy, J.-G. Parent et A. Asselin
}

Volume 72, numéro 2, 1991

URI : https://id.erudit.org/iderudit/706007ar

DOI : https://doi.org/10.7202/706007ar

Aller au sommaire du numéro

Éditeur(s)

Société de protection des plantes du Québec (SPPQ)l

ISSN

0031-9511 (imprimé)

1710-1603 (numérique)

Découvrir la revue

Citer cet article

Audy, P., Parent, J.-G. \& Asselin, A. (1991). A note on four nonradioactive

labeling systems for dot hybridization detection of potato viruses.

Phytoprotection, 72(2), 81-86. https://doi.org/10.7202/706007ar
Résumé de l'article

Des clones d'ADN complémentaire ont été fabriqués à partir des ARN génomiques des virus $\mathrm{S}(\mathrm{PVS}), \mathrm{X}(\mathrm{PVX})$ et $\mathrm{Y}$ (PVY) de la pomme de terre (Solarium tuberosum). Les clones ont été sélectionnés pour leur spécificité par l'hybridation avec divers ARN viraux. Les clones S12 de PVS et X6 de PVX se sont avérés très spécifiques à l'ARN de PVS et PVX respectivement, alors que le clone Y10 de PVY a hybride fortement à l'ARN du PVY et faiblement à l'ARN du PVS. Quatre systèmes commerciaux non radioactifs de marquage des acides nucléiques et de détection ont été comparés entre eux et avec le marquage radioactif traditionnel de la sonde $\mathrm{au}^{32} \mathrm{P}$. La détection colorimétrique de sondes d'ADN marquées à la digoxygénine permet de déceler $1 \mathrm{ng}$ de virions (60 pg d'ARN), soit une sensibilité du même ordre que l'autoradiographie avec des sondes marquées au phosphore radioactif. Les sondes sulfonées, biotinylées et marquées à la peroxydase ont été moins sensibles en permettant la détection de $600 \mathrm{pg}$ d'ARN viral. 


\title{
A note on four nonradioactive labeling systems for dot hybridization detection of potato viruses
}

\author{
Patrice Audy \\ Département de phytologie, Faculté des Sciences de l'Agriculture et de l'Alimentation, Université \\ Laval, Québec (Québec) Canada G1K 7P4. Present address: Department of Plant Pathology, Plant \\ Science Building, Cornell University, Ithaca, New York 14853-5908, USA.
}

\section{Jean-Guy Parent}

Service de phytotechnie de Québec, Ministère de l'Agriculture, des Pêcheries et de l'Alimentation du Québec, Complexe scientifique, 2700, rue Einstein, Sainte-Foy (Québec), Canada G1P 3W8

\author{
Alain Asselin' \\ Département de phytologie, Faculté des Sciences de l'Agriculture et de l'Alimentation, \\ Université Laval, Québec (Québec), Canada G1K 7P4 \\ 'To whom correspondence should be addressed.
}

(Received 1991-05-30; accepted 1991-09-16)

\begin{abstract}
Complementary DNA clones of genomic RNAs of potato (Solanum tuberosum) viruses S (PVS), X (PVX) and Y (PVY) were produced and tested for their capacity to hybridize with various plant virus RNAs. PVS clone S12 and PVX clone X6 were found to be very specific to PVS and PVX RNA respectively, whereas PVY clone Y10 strongly hybridized with PVY RNA and weakly with PVS RNA. Four commercial, nonradioactive systems of nucleic acid labeling and detection were compared to the usual ${ }^{32} \mathrm{P}$-labeled probe using dot hybridization experiments. Colorimetric detection of digoxigeninlabeled DNA probes gave a level of sensitivity of $1 \mathrm{ng}$ of virions ( $60 \mathrm{pg}$ of RNA), similar to autoradiography of ${ }^{32} \mathrm{P}-$ labeled probes. Sulfonated, biotinylated and peroxidase-labeled probes were slightly less sensitive, allowing detection of $600 \mathrm{pg}$ of viral RNA.
\end{abstract}

Audy, P., J.-G. Parent, and A. Asselin. 1991. A note on four nonradioactive labeling systems for dot hybridization detection of potato viruses. PHYTOPROTECTION 72: 81-86.

Des clones d'ADN complémentaire ont été fabriqués à partir des ARN génomiques des virus $\mathrm{S}$ (PVS), X (PVX) et Y (PVY) de la pomme de terre (Solanum tuberosum). Les clones ont été sélectionnés pour leur spécificité par l'hybridation avec divers ARN viraux. Les clones S12 de PVS et X6 de PVX se sont avérés très spécifiques à l'ARN de PVS et PVX respectivement, alors que le clone Y10 de PVY a hybridé fortement à l'ARN du PVY et faiblement à l'ARN du PVS. Quatre systèmes commerciaux non radioactifs de marquage des acides nucléiques et de détection ont été comparés entre eux et avec le marquage radioactif traditionnel de la sonde au ${ }^{32} \mathrm{P}$. La détection colorimétrique de sondes d'ADN marquées à la digoxygénine permet de déceler 1 ng de virions ( 60 pg d'ARN), soit une sensibilité du même ordre que l'autoradiographie avec des sondes marquées au phosphore radioactif. Les sondes sulfonées, biotinylées et marquées à la peroxydase ont été moins sensibles en permettant la détection de 600 pg d'ARN viral.

Potato viruses S (PVS), X (PVX) and Y (PVY) cause economically important losses in potato (Solanum tuberosum L.) production. Reductions in tuber yields of infected plants of $30 \%, 37 \%$ and $80 \%$ have been reported (de Bokx and Huttinga 1981; Wright 1970, 1977). PVY and some PVS isolates that are aphid transmitted (Kostiw 1979; Wardrop et al. 1989), and PVX that is easily mechanically transmitted, often cause rapid reinfection of virus-free potato seed plants in the field (McDonald 1987). Detection of early viral infec- tions in seed stocks is important to maintain high standards required by certification agencies.

Serological techniques, specially ELISA, are commonly used to diagnose viral diseases in potato (Zink 1991). Recent advances in molecular biology have led to the development of nucleic acid probes for the sensitive detection and identification of plant viruses. These probes are at least as sensitive as ELISA (Barbara et al. 1987; Roy et al. 1988; Stenger et al. 1987; van der Vlugt et al. 1988) and, in some cases, a ten-fold increase in comparative sensitivity has been reported (Bijaisoradat and 
Kuhn 1988; Eweida et al. 1990; Pesic and Hiruki 1988; Varveri et al. 1987). Molecular hybridization methods have been used to detect various potato viruses (Baulcombe and Fernandez-Northcote 1988; Baulcombe et al. 1984; Monis and de Zoeten 1990b; Waterhouse et al. 1986). Unfortunately, molecular probes are not widely used because they are usually labeled with ${ }^{32} \mathrm{P}$-nucleotides. Radiation safety, rapid decay of some radioisotopes and storage of radioactive waste are major restrictions for routine diagnostic procedures (Hopp et al. 1988). Nonradioactive nucleic acid labeling and detection approaches have recently emerged as alternatives to the use of radioactivity in nucleic acid hybridization experiments (Eweida et al. 1989; Hopp et al. 1988; Roy et al. 1988). The objectives of the present study were to prepare cDNA clones from PVS, PVX and PVY RNAs and to use them as probes to evaluate new commercial, nonradioactive systems of labeling.

Potato plants infected with local isolates of PVS, PVX and PVY were obtained from Agriculture Canada (La Pocatière, Québec). Tomato mosaic virus (ToMV) and tobacco mosaic virus (TMV), strain $\mathrm{U}_{1}$, were purified from infected Nicotiana tabacum L. cv. Turkish Samsun according to Gooding and Hebert (1967). Barley stripe mosaic virus (BSMV) was purified from infected Hordeum vulgare L. cv. Sophie according to Jackson and Brakke (1973). PVX, PVY and PVS were maintained under greenhouse conditions in $N$. tabacum cv. Xanthi-nc (PVX and PVY) and potato cv. Superior (PVS) plants. Viruses were purified from infected leaves as described by Shepard (1972) except that urea (1 M) was added to the buffer after each polyethylene glycol precipitation for PVS and PVY. Viral RNAs were isolated from purified virions by heating at $50^{\circ} \mathrm{C}$ for $5 \mathrm{~min}$ in the presence of $0.5 \%$ sodium dodecyl sulfate (SDS). RNA was extracted twice with an equal volume of phenol:chloroform (1:1) and precipitated with ethanol.

The genomes of PVS, PVX and PVY consist of a single-stranded positive sense RNA of $7.5,6.4$ and $9.7 \mathrm{~kb}$, respectively, and contain a 3 -terminal polyadenylated region (Huisman et al. 1988; Monis and de Zoeten 1990a; Turpen 1989). First strand synthesis of PVS, PVX and PVY cDNAs was carried out with Moloney murine leukemia virus reverse tran- scriptase (Pharmacia) using oligoprimers (6bp) for PVX RNA and oligo-dT12-18 primer for PVS and PVY RNAs. Second strand synthesis was performed according to Gubler and Hoffman (1983) using a commercial kit (cDNA synthesis kit, Pharmacia). Virus cDNAs were blunt-ended with the Klenow fragment of DNA polymerase I, ligated to EcoRI linkers with T4 DNA ligase and inserted into the EcoRI site of $\lambda$ gt 10 for PVX or in B-galactosidase lac-Z gene of pT7T3 18U (Pharmacia) for PVS and PVY. Forty PVX- $\lambda$ gt 10 plaques chosen at random from a phage library and multiplied by plating on Escherichia coli C600. Their cDNA inserts were digested with EcoRI and subcloned into pUC 13. Competent E. coli NM522 or JM103 cells (Mandel and Higa 1970) were transformed by the plasmids containing cDNAs. With each viral cDNA made by oligo (dT) priming, we isolated approximately 40 ampicillin-resistant and B-galactosidase negative plasmids using isopropyl- $\beta-\mathrm{D}$-thiogalactoside (IPTG) and 5bromo-4-chloro-3-indolyl-B-D-galactoside (Xgal). The presence and size of inserts was determined by plasmid isolation (Birnboim and Doly 1979) followed by EcoRI digestion and electrophoresis on agarose gel with DNA size markers (123 bp DNA ladder, Bethesda Research Laboratories). Clones with an insert size of approximatively $3.0 \mathrm{~kb}$ for PVS and PVY and $1.0 \mathrm{~kb}$ for PVX were selected and ${ }^{32} \mathrm{P}$-labeled to test their specificity against a few purified plant viruses using nucleic acid dot hybridization (Fig. 1).

To compare detection systems, plasmids containing viral cDNAs were radioactively labeled by random priming (Feinberg and Vogelstein 1983) with $\alpha^{32} \mathrm{P}-\mathrm{dCTP}$ (oligolabeling kit, Pharmacia). Digoxigenin-11-dUTP (Boehringer Mannheim) and biotin-14-dATP (Bethesda Research Laboratories) were also incorporated into plasmids respectively by random priming and nick translation, whereas sulfonation (FMC BioProducts) and direct peroxidase labeling of DNA (Amersham) were performed according to the instructions of the manufacturers.

Purified virus solutions were serially diluted with $1 \%$ SDS, boiled 5 min and spotted (5 $\mu \mathrm{L}$ ) onto nylon membranes (Nytran, Schleicher and Schuell). Viral RNAs were exposed to UV (transilluminator TS-15 Chromato-vue) for $3 \mathrm{~min}$ at $20 \mathrm{~cm}$ from the source (Church and Gilbert 1984). Hybridization conditions and 
detection were performed according to the manufacturers' directions for nonradioactive systems. With ${ }^{32} \mathrm{P}$-labeled probes, prehybridization was carried out for $4 \mathrm{~h}$ in sealed polyethylene bags at $42^{\circ} \mathrm{C}$ in $50 \%$ formamide (Sigma), 2X Denhardt's solution (1X is $0.02 \%$ Ficoll, $0.02 \%$ polyvinylpyrrolidone and $0.02 \%$ bovine serum albumin, all from Sigma), $5 \mathrm{X}$ $\mathrm{SSC}$ ( $1 \mathrm{X}$ is $150 \mathrm{mM} \mathrm{NaCl}$ and $15 \mathrm{mM}$ sodium citrate, $\mathrm{pH}$ 7.0), 10\% dextran sulfate (Sigma), $0.1 \%$ SDS and $0.1 \mathrm{mg} / \mathrm{mL}$ of denaturated salmon-sperm DNA (Sigma). Hybridizations with ${ }^{32} \mathrm{P}$-labelled DNA were performed at $42^{\circ} \mathrm{C}$ for $16 \mathrm{~h}$ in prehybridization mixture, except that salmon-sperm DNA was at $0.5 \mathrm{mg}$ / $\mathrm{mL}$. These hybridizations were performed in the presence of $20 \mathrm{ng}$ of labeled probes per $\mathrm{cm}^{2}$ of membrane. ${ }^{32} \mathrm{P}$-labeled probes had a specific activity of at least $1.5 \times 10^{6} \mathrm{cpm} / \mu \mathrm{g}$ DNA. Membranes were washed twice, $10 \mathrm{~min}$ each, in $2 \mathrm{X} \mathrm{SSC}$ and $0.1 \% \mathrm{SDS}$ at room temperature, $30 \mathrm{~min}$ in $2 \mathrm{X} \mathrm{SSC}$ and $0.1 \% \mathrm{SDS}$ at $42^{\circ} \mathrm{C}$ and twice (30 min each) in 0.1X SSC and $0.1 \%$ $\mathrm{SDS}$ at $42^{\circ} \mathrm{C}$. Autoradiography was for 6 to 8 $\mathrm{h}$ at $-70^{\circ} \mathrm{C}$ with an intensifying screen using Kodak XAR-2 films. Each of the experiments was repeated at least twice.

Radioactively labeled PVS clone S12, PVX clone X6 and PVY clone Y10 were tested for their specificity against a few plant viruses (Fig. 1). PVS clone S12 (Fig. 1B) and PVX clone X6 (Fig. 1C) were quite specific, hybridizing strongly with PVS or PVX RNA but poorly with the heterologous viral RNAs. PVY clone Y 10 hybridized strongly with PVY RNA but also hybridized to BSMV, ToMV, TMV, PVX and PVS (Fig. 1A). Higher specificity was obtained using more stringent conditions but PVS RNA still cross-hybridized with PVY probe Y10, but TMV and BSMV were not tested (Fig. 2A). To potentially decrease the unwanted hybridization, the inserted fragment of $1.6 \mathrm{~kb}$ obtained by EcoRI digestion of plasmid Y10 was purified and ${ }^{32} \mathrm{P}$-labeled. The same hybridization specificity was observed. In addition, this fragment bound to oligo(dT)cellulose revealing the presence of a poly(A) track or a very A-rich region in PVY plasmid Y10. However, this does not explain the hybridization with polyadenylated PVS RNA since no cross-hybridization was observed with polyadenylated PVX RNA. Pairwise computer alignments between available nucleotide sequences of PVY (Robaglia et al. 1989) and PVS
(McKenzie et al. 1989) revealed a $72 \%$ homology for a region of 93 residues located at 2500 (PVY) and 2800 (PVS) residues downstream their 3' end (data not shown). Homology even reached $81 \%$ for a stretch of 26 nucleotides. This could be sufficient to give significant hybridization signal between PVS RNA and PVY Y10 probe. According to the size of the PVS fragment cloned, this region is absent from the PVS S12 probe. That is probably why PVS S12 probes did not hybridize with PVY RNA. Fordiagnostic purposes, PVY Y10 probe should be modified to eliminate this region of strong homology with PVS RNA.

The sensitivity of four commercial systems of probe labeling and detection was compared to the usual ${ }^{32} \mathrm{P}$-labeled DNA method using dot hybridization procedures. Two of these systems were based on a colorimetric reaction from alkaline phosphatase-linked antibodies that were bound with either antigenic digoxigenin molecules (Boehringer Mannheim) or

A

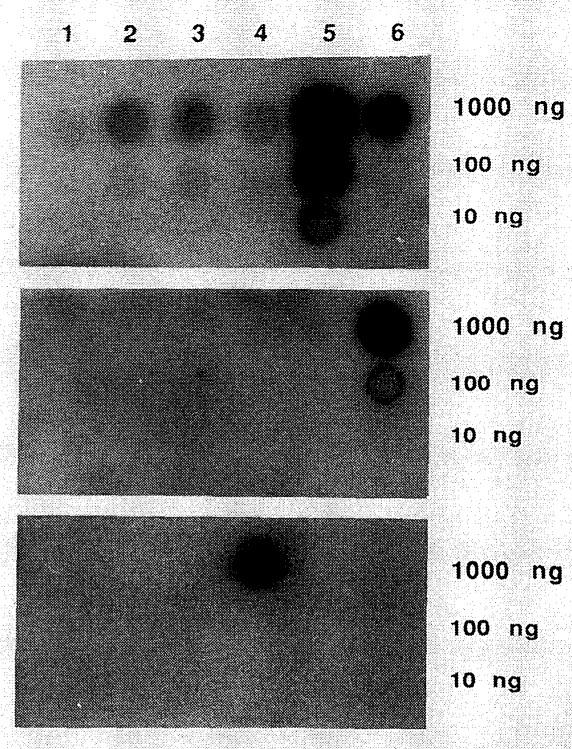

Figure 1. Dot blot hybridization of viral RNAs using ${ }^{32}$ P-labeled (A) PVY probe Y10, (B) PVS probe $\mathrm{S} 12$ and $(\mathbf{C}) \mathrm{PVX}$ probe $\mathrm{X} 6$. Purified BSMV (1), ToMV (2), TMV (3), PVX (4), PVY (5) and PVS (6) were serially diluted, denatured in the presence of SDS and spotted onto nylon sheets. Hybridizations were performed in the presence of $20 \mathrm{ng}$ of labeled probes per $\mathrm{cm}^{2}$ of membrane. ${ }^{32} \mathrm{P}$-labeled probes had a specific activity of at least $1.5 \mathrm{x}$ $10^{6} \mathrm{cpm} / \mu \mathrm{g}$ DNA. Autoradiography was for $8 \mathrm{~h}$ with XAR-2 Kodak films at $-70^{\circ} \mathrm{C}$. 
sulfone groups (FMC BioProducts) attached to modified nucleotides. The two others involved detection with X-ray films of luminescence emitted from enzymatic reactions using streptavidin-alkaline phosphatase conjugates on a biotin-labeled probe (Bethesda Research Laboratories) or a peroxidase-labeled probe (Amersham). Hybridizations were performed in the presence of $8 \mathrm{ng}$ of labeled probes per $\mathrm{cm}^{2}$ of membrane. The ${ }^{32} \mathrm{P}$-labeled probe had a specific activity of $4.5 \times 10^{8} \mathrm{cpm} / \mu \mathrm{g}$ DNA.

The detection limit using ${ }^{32} \mathrm{P}$-labeled probe Y 10 was close to 1.0 ng of PVY virions (very faint spot) or $60 \mathrm{pg}$ of viral RNA (assuming 6\% RNA per particle)(de Bokx and Huttinga 1981)

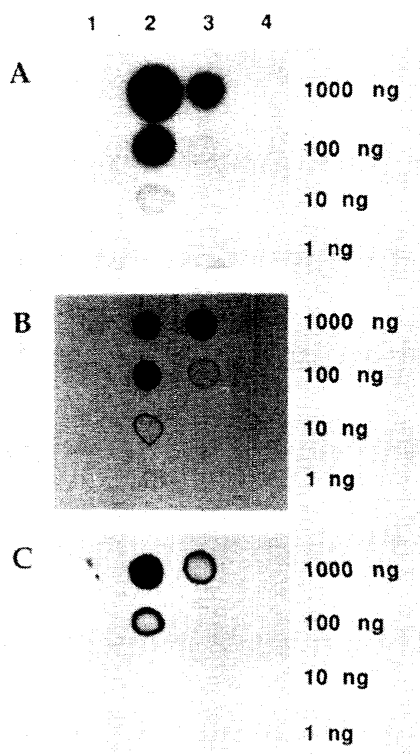

Figure 2. Dot blot hybridization of various viral RNAs using (A) ${ }^{32} \mathrm{P}-$, (B) digoxigenin, and (C) peroxidase- labeled PVY cDNA probe Y10. Purified ToMV (1), PVY (2), PVS (3) and PVX (4) were serially diluted, denatured in the presence of SDS and spotted onto nylon sheets. Hybridization and detection of nonradioactive probes were performed according to the manufacturers' instructions. Standard procedures were used for radioactive probes. Hybridizations were performed in the presence of $8 \mathrm{ng}$ of labeled probes per $\mathrm{cm}^{2}$ of membrane. The ${ }^{32} \mathrm{P}$-labeled probe had a specific activity of $4.5 \times 10^{8} \mathrm{cpm} / \mu \mathrm{g}$ DNA. Autoradiography was for $6 \mathrm{~h}$ with XAR-2 Kodak films at $-70^{\circ} \mathrm{C}$. Hybridized peroxidase-labeled probes were detected by enhanced chemiluminescence using a $60 \mathrm{~min}$ exposure to a XAR-2 Kodak film at $22^{\circ} \mathrm{C}$. Hybridization signals of digoxigenin-labeled probes were developed during $6 \mathrm{~h}$ at $22^{\circ} \mathrm{C}$. for a 6-h exposure (Fig. 2A). The same level of detection was obtained using colorimetric-digoxigenin labeling after $6 \mathrm{~h}$ of enzymatic development (Fig. 2B). Similar results were obtained with the PVS probe S12 and PVX probe X6 (data not shown). In the latter case, however, the digoxigenin probe concentration was raised to $25-50 \mathrm{ng} / \mathrm{mL}$ to obtain a sensitivity equivalent to radioactive labeling.

Luminescent-peroxidase Y10 probe was 5 to 10 times less sensitive than colorimetric detection of digoxigenin-labeled probe (Fig. 2C). Similar results were obtained with biotin-labeled probes (data not shown). In spite of their lower level of sensitivity, the two systems based on photographic detection of luminescent DNA probes, have the advantage of being completely independent from the color of tissue samples. Such colored samples can create significant problems with colorimetric methods using dot hybridization of plant extracts (Eweida et al. 1989; Hopp et al. 1988; ).

At typical probe concentration, sulfonated probes were slightly less sensitive (data not shown) and required more time-consuming manipulations. In addition, sulfonated X6 probes could be as sensitive as digoxigeninlabeled probes if they were used at concentration of $600-1000 \mathrm{ng} / \mathrm{mL}$ (24 times more concentrated than digoxigenin probes). Sulfonated probes have also been found less sensitive than biotinylated probes in dot blot hybridization procedures (Johansen et al. 1989). Because of the presence of biotin-like components in plant material (Cuppels et al. 1990; Hull and Al-Hakim 1988), sulfonated probes could possibly yield a better level of detection in plant extracts because of lower background reactions. Such problems arising with biotinylated probes could be alleviated when DNAs of plant extracts are purified (Roy et al. 1988).

Since the early 1980s, nonradioactive probes emerged slowly as an alternative to the use of radioactivity to label nucleic acids. The sensitivity of digoxigenin-labeled probes and the speed of detection have been reported to be comparable to those of ${ }^{32} \mathrm{P}$-labeled probes in dot blot assays and appeared to be superior to other nonradioactive systems (Lion and Haas 1990). However, for plant virus detection, a biotin probe gave a sensitivity of detection similar to a ${ }^{32} \mathrm{P}$-labeled probe (Roy 
et al. 1988). Moreover, the detection level using biotinylated RNA probes has been reported to be high enough to detect femtograms of PVS RNA (Eweida et al. 1989).

In this study, we have tested four commercial, nonradioactive DNA labeling kits for dot hybridization detection of PVS, PVX and PVY RNAs. As little as 60 pg of viral RNAs could be detected within $6 \mathrm{~h}$ of enzymatic development using colorimetric-digoxigenin labeling system. This detection level was similar to that obtained with ${ }^{32} \mathrm{P}$-labeled probes for the same exposure time. The other systems of labeling gave a lower level of sensitivity. However, the enhanced peroxidase chemiluminescence system (Amersham), involving direct labeling of DNA probe (Renz and Kurz 1984), was found to be the most convenient approach for largescale detection of specific nucleic acid sequences. Probe labeling with peroxidase is very short $(10 \mathrm{~min})$ and detection of probes after washings can be obtained within $60 \mathrm{~min}$. Only purified virus was used, and the utility of the nonradioactive labelled probes to detect virus in plants remains to be determined.

This work was funded by a contract from the Ministère de l'Agriculture, des Pêcheries et de l'Alimentation du Québec (MAPAQ). The authors thank Mr. Pierre Sylvestre from Agriculture Canada (La Pocatière) for providing virus isolates and Mrs. Danièle Pagé for her technical work with PVX clones. We also acknowledge the secretarial support of Myriam Kearns.

Barbara, D.J., E.E. Kawata, P.P. Ueng, R.M. Lister, and B.A. Larkins. 1987. Production of cDNA clones from the MAV isolate of barley yellow dwarf virus. J. Gen. Virol. 68: 2419-2427.

Baulcombe, D., R.B. Flavell, R.E. Boulton, and G.J. Jellis. 1984. The sensitivity and specificity of a rapid nucleic acid hybridization method for the detection of potato virus X in crude sap samples. Plant Pathol. 33: 361-370.

Baulcombe, D.C., and E.N. Fernandez-Northcote. 1988. Detection of strains of potato $X$ and a broad spectrum of potato $\mathrm{Y}$ isolates by nucleic acid spot hybridization (NASH). Plant Dis. 72: 307-309.

Bijaisoradat, M., and C.W. Kuhn. 1988. Detection of two viruses in peanut seeds by complementary DNA hybridization tests. Plant Dis. 72: 956-959.

Birnboim, H.C., and J. Doly. 1979. A rapid alkaline extraction procedure for screening recombinant plasmid DNA. Nucl. Acids Res. 7: $1513-1523$.
Church, G.M., and W. Gilbert. 1984. Genomic sequencing. Proc. Natl. Acad. Sci. USA 81: 19911995.

Cuppels, D.A., R.A. Moore, and V.L. Morris. 1990. Construction and use of a nonradioactive DNA hybridization probe for detection of Pseudomonas syringae pv. Tomato on tomato plants. Appl. Environ. Microbiol. 56: 1743-1749.

de Bokx, J.A., and H. Huttinga. 1981. Potato virus Y. In: Description of plant viruses. No 242. Commonw. Mycol. Inst./Assoc. Appl. Biol. 6 pp.

Eweida, M., T.L. Sit, and M.G. Abouhaidar. 1989. Molecular cloning of the genome of the carlavirus potato virus S: biotinylated RNA transcripts for virus detection in crude potato extracts. Ann. Appl. Biol. 115: 253-261.

Eweida, M., H. Xu, R.P.Singh, and M.G. Abouhaidar. 1990. Comparison between ELISA and biotin-labelled probes from cloned cDNA of potato virus $\mathrm{X}$ for the detection of virus in crude tuber extracts. Plant Pathol. 39: 623-628.

Feinberg, A.P., and B. Vogelstein. 1983. A technique for radiolabelling DNA restriction endonuclease fragments to high-specific activity. Anal. Biochem. 132: 6-13.

Gooding, G.V., Jr., and T.T. Hebert. 1967. A simple technique for purification of tobacco mosaic virus in large quantities. Phytopathology 57: 1285.

Gubler, U., and B.J. Hoffman. 1983. A simple and very efficient method for generating cDNA libraries. Gene 25: 263-269.

Hopp, H.E., L. Giavedoni, M.A. Mandel, A. Arese, B. Orman, F. Bravo, H. Almonacid, H.N. Torres, and A.N. Mentaberry. 1988. Biotinylated nucleic acid hybridization probes for potato virus detection. Arch. Virol. 103: 231-241.

Huisman, M.J., H.J.M. Linthorst, J.F. Bol, and B.J.C. Cornelissen. 1988. The complete nucleotide sequence of potato virus $\mathrm{X}$ and its homologies at the amino acid level with various plus-stranded RNA viruses. J. Gen. Virol. 69: 1789-1798.

Hull, R., and A. Al-Hakim. 1988. Nucleic acid hybridization in plant virus diagnosis and characterization. Trends Biotechnol. 6: 213-218.

Jackson, A.O., and M.K. Brakke. 1973. Multicomponent properties of barley stripe mosaic virus ribonucleic acid. Virology 55: 483-494.

Johansen, I.E., O.F. Rasmussen, and M. Heide. 1989. Specific identification of Clavibacter michiganense subsp. sepedonicum by DNA-hybridization probes. Phytopathology 79: 1019-1023.

Kostiw, M. 1979. Transmission of potato virus Y by Rhopalosiphum padi L. Potato Res. 22: 237-238.

Lion,T., and O.A. Haas. 1990. Nonradioactive labeling of probe with digoxigenin by polymerase chain reaction. Anal. Biochem.188: 335-337.

Mandel, M., and A. Higa. 1970. Calcium dependent bacteriophage DNA infection. J. Mol. Biol. 53: 154162.

McDonald, J.G. 1987. Comparative levels of potato viruses $S$ and $Y$ infection of microplants and tuberpropagated plants in the field. Am. Potato J. 64: 517521. 
McKenzie, D.J., J.H. Tremaine, and R. Stace-Smith. 1989. Organization and interviral homologies of the 3'-terminal portion of potato virus S RNA. J. Gen. Virol. 70: 1053-1063.

Monis, J., and G.A. de Zoeten. 1990a. Characterization and translation studies of potato virus S RNA. Phytopathology 80: 441-445.

Monis, J., and G.A. de Zoeten. 1990b. Molecular cloning and physical mapping of potato virus S complementary DNA. Phytopathology 80: 446-450.

Pesic, Z., and C. Hiruki. 1988. Comparison of ELISA and dot-hybridization for detection of alfalfa mosaic virus in alfalfa pollen. Can. J. Plant Pathol. 10: 116-122.

Renz, M., and C. Kurz. 1984. A colorimetric method for DNA hybridization. Nucl. Acids Res. 12: 3455-3444.

Robaglia, C., M. Durand-Tardif, M. Tronchet, G. Boudazin, S. Aster-Manifacier, and F. Casse-Delbart. 1989. Nucleotide sequence of potato virus Y $(\mathrm{N}$ strain) genomic RNA. J. Gen. Virol. 70: 935-947.

Roy, B.P., M.G. AbouHaidar, T.L. Sit, and A. Alexander. 1988. Construction and use of cloned cDNA biotin and ${ }^{32} \mathrm{P}$-labeled probes for the detection of papaya mosaic potexvirus RNA in plants. Phytopathology 78: 1425-1429.

Shepard, J.F. 1972. Gel diffusion methods for the serological detection of potato virus X, S and M. Montana Agric. Exp. Stn. Bull. 622. Montana State University, Boseman, $72 \mathrm{pp}$.
Stenger, D.C., R.H. Mullin, and T.J. Morris. 1987. Characterization and detection of the strawberry necrotic shock isolate of tobacco streak virus. Phytopathology 77: 1330-1337.

Turpen, T. 1989. Molecular cloning of a potato virus $Y$ genome: nucleotide sequence homology in non-coding regions of potyvirus. J. Gen. Virol. 70: 1951-1960.

van der Vlugt, C.I.M., H.J.M. Linthorst, C.J. Asjes, A.R. van Schadewijk, and J.F. Bol. 1988. Detection of tobacco rattle virus in different parts of tulip by ELISA and complementary DNA hybridization assays. Neth. J. Plant Pathol. 94: 149-160.

Varveri, C., M. Ravelonandro, and J. Dunez. 1987. Construction and use of a cloned cDNA probe for the detection of plum pox virus in plants. Phytopathology 77: 1221-1224.

Wardrop, E.A., A.B. Gray, R.P. Singh, and J.F. Peterson. 1989. Aphid transmission of potato virus $\mathrm{S}$. Am Potato J. 66: 449-459.

Waterhouse, P.M., W.L. Gerlach, and W.A. Miller. 1986. Serotype-specific and general luteovirus probes from cloned cDNA sequences of barley yellow dwarf virus. J. Gen. Virol. 67: 1273-1281.

Wright, N.S. 1970. Combined effects of potato viruses $X$ and $\mathrm{S}$ on yield of Netted Gem and White Rose potatoes. Am. Potato J. 47: 475-478.

Wright, N.S. 1977. The effect of separate infection by potato virus $\mathrm{X}$ and $\mathrm{S}$ on Netted Gem potato. Am. Potato J. 54: 147-149.

Zink, R.T. 1991. Pathogen detection in seed potato. Am. Potato J. 68: 103-105. 